\title{
Sustainability Organic Agriculture and Livestock Production with Respect to European Union in Eastern Anatolia and East Black Sea Regions
}

\author{
Vecihi Aksakal $^{1}$, Sümer Haşimoğlu ${ }^{2 *}$, Bahri Bayram ${ }^{3}$, Gürsel Dellal $^{4}$, Yaşar Erdoğan ${ }^{1}$, \\ Hilal Ürüşan Altun ${ }^{1}$, Mahir Murat Cengiz ${ }^{5}$
}

${ }^{1}$ Veterinary Department, Bayburt Vocational School, Bayburt University, 69000 Bayburt, Turkey

${ }^{2}$ Retired lecturer, 19053 Schwerin, Germany

${ }^{3}$ Organic Agriculture Department, Kelkit Aydın Doğan Vocational School, Gümüşhane University, 29600 Kelkit/Gümüşhane, Turkey

${ }^{4}$ Animal Science Department, The Faculty of Agriculture, Ankara University, 06110 Ankara, Turkey

${ }^{5}$ Equine and Training Department, Erzurum Vocational School, Atatürk University, 25100 Erzurum, Turkey

A R T I C L E I N F O

Article history:

Received 26 April 2016

Accepted 27 August 2016

Available online, ISSN: 2148-127X

Keywords:

Organic Agriculture

Livestock

Farmers

Rural Development

Eastern Anatolian

${ }^{*}$ Corresponding Author:

E-mail: eshasimoglu@yahoo.com A B S T R A C T

The majority of farm households in Turkey and especially the Eastern Anatolia are still based on low-input semi subsistence agriculture and livestock production. Despite a slow decline in recent years, agriculture and livestock production remains a major employer in Turkey and it is a significant contributor to the country's gross domestic product, GDP. Whist Turkey is one of the EU candidate countries, is self sufficient in food production and Turkish agriculture is poorly structured inefficient, with farming in the Eastern Anatolia being mainly subsistence farming. Yet, these traditional rural structures combined with poor access to low level of education and low level of off-farm unemployment problem makes the situation more complicated and unsustainable. The best way to promote sustainability, better and higher production of Eastern Anatolian and rural Turkey is to invest in the local people, villages through improved, continuing and effective agricultural and livestock programs in particular. Investment in human capital especially in the rural areas leads to more employment opportunities through entrepreneurship and innovation in organic agriculture and livestock production. A holistic approach to developing and improving supply chains could unlock the potential for sophisticated, state-of-the-art organic agriculture and livestock producers and businesses in the region to become EU and global players. Eastern Anatolian livestock producers and the farmers have the ambitions to take part in future progress because the region is naturally organic not by design but default. It is for sure that present potential of the region has not been fully determined and utilized. EU has greatly benefited from previous enlargements economically, politically and socially. When European Union (EU) and Turkish Government relations considered and accession of Turkey to EU would be the logical consequence of the previous accessions. The screening on chapter 11 (Agriculture and rural development) is one of the important criteria and Turkey is working on to meet these benchmarks.

\section{Introduction}

It has been agreed on that the structural change is always needed to make the rural development and economic improvement to be innovative and EU and US competitive. Eastern Anatolian rural areas will remain a political and economic liability due to its rampant underemployment problem that stimulates the migration from the region. Social policy is not in a position to create employment through new markets. It is for sure that the investments are not enough for the region. In this context Eastern Anatolian current effort to make organic agriculture more compatible with the western regions and EU that requires a new ways of looking at the sustainable agriculture in the region. It requires a new domestic policy approach to rural development that it focused on villages through more investment in human capital, especially young girls and women that will create entrepreneurial structure. In Eastern Anatolia women play a vital role in advancing agricultural development and food security and safety. They participate in many aspects of rural life - in paid employment, trade and marketing, as well as many unpaid activities, such as tending to crop and farm animals, collecting water and wood for fuel, and caring for family members. Women also manage household consumption and food preparation. But women face many constraints in the multiple activities they pursue - less land ownership, access to credit, extension and other services, and ability to hire labor. In the region, too often, these constraints as well as women's current and potential contributions to agriculture and organic agriculture and livestock production go unrecognized (Haşimoğlu, 2013). 
Societal views of women's roles restrict women's input in household decisions. Such beliefs also limit their access to land ownership, farm equipment and credit - all of which are needed to be economically successful. These barriers ultimately inhibit women's ability to produce, and can make it difficult for them to escape poverty or provide food for their families. In addition to above disadvantages of socio-economic development women face with violation in human rights such as intra-family violence, social and cultural oppression, and honor killings. This type of violence transferred to major big cities of Turkey through the massive migration (Haşimoğlu, 2013).

The one of the answer is spreading the development of the organic agriculture in the region in a systematic and traditional way. Increasing opportunities for women can have a powerful impact on productivity and agricultureled growth. Women are just as efficient agricultural producers as men and can achieve similar activities when given equal access to resources, including training and services. When women's productivity and incomes increase, the benefits amplify across families and generations. Women tend to devote a larger fraction of their income to their children's health and nutrition, laying the foundation for their children's lifelong cognitive and physical development (Karagel, 2010; Haşimoğlu, 2013).

In this context, Turkey is a major producer and exporter of various agricultural products. The initiation of organic agriculture in Turkey started from foreign demand which were made by the companies of European Union (EU) rather than domestic demand. Geographical potential of Turkey with different seven geographic regions encourages the growing of many organic products that are peculiar for each region. From the organic agricultural production point of view another advantage of Turkey is that most of the land has not been polluted with chemicals, fertilizers, herbicides and pesticides, and Eastern Anatolian region is very appropriate for this situation. Because livestock and crop yields and quality are poor, due to a number of factors (e.g. poor soil quality, degradation and falling fertility, poor genetic base of livestock and seeds, poor quality forage etc..), resulting in low farm household incomes to buy chemicals. People utilize a range of livelihood strategies and coping mechanisms to survive, but are heavily reliant on state support/handouts, and off-farm income - especially casual and seasonal employment. Organic agriculture of Turkey has so far rarely managed to be part of a broad-based vision for national organizations, governments or donor agencies in addressing national issues, particularly Eastern Anatolian issues.

The majority of farm households in Turkey and especially in the Eastern Anatolia still based on low-input, low income semi subsistence agriculture and livestock production. This low productivity does not create an immediate threat in terms of hunger or malnutrition. Most farmers enjoy the minimal living standards of living, and they still share what they have with their guests and close relatives. On the other hand traditional rural structures combined with no education or poor education opportunities and limited number of off-farm employment produce high unemployment that is socially unsustainable and cause migration from the region. Frustration with the very slow economic development and low future prospect create social, political, religious and especially in the Eastern Anatolia ethnic conflicts. No trust in the formal institutions and reactions to those slows down the cultural, educational and economic development. Rural development policies especially aiming women and investing in human capital will facilitate more exchange among groups and peaceful interactions and also tolerance among groups within Eastern Anatolia also between EU and global cultures.

\section{Methodology}

The human impact on the global ecosystem has reached planetary levels, causing holes in the ozone layer, global warming, and the loss of natural resources such as clean seas, forests, fossil fuels and agricultural area. At the same time, poverty and inequality have not been eradicated.

The Agriculture Strategy (Organic and conventional) of Turkey for the next ten years has set the main aims of agriculture as to constitute an agriculture sector sustainable, highly competitive and organised by taking into account economic, social, environmental and international development dimensions within the principle of the utilization of the resources effectively. In this framework, the agricultural support measures have been re-identified by Ministry of Agriculture and Livestock Production (MALP, 2013). Our observation is that corporations were able to react faster and more effectively to the reality of increased international integration (EU) than governments. While governance systems are still in the process of adaptation and Turkey is not an exception. One should not forget that the government mostly acts on the basis of hierarchical control, demanding compliance with its rules and able to enforce them with through the hegemony of law and order. The agriculture market functions through fragmented competition in a more or less free market, where order is attained through the Invisible Hand governing (Management) on the basis of efficiency to push it to the maximum. That interrelation needs to be balanced toward agricultural producers and associations (Haşimoğlu, 2016).

With one arm reaching out to Asia and the other to Europe, Turkey is the unique country that bridges two continents in the world. Considering the geographical marketing position advantage, Ministry of Agriculture has determined to improve the Turkish organic and conventional agriculture and livestock production on the determined pillars given below. The plan was renewed in 2012 and the 2013-2017 Strategic Plan of the Ministry of Food Agriculture and Livestock was setup, (MALP, 2013).

Six strategic areas have been determined within the scope of the Plan:

- Agricultural production and Security of Supply,

- Food Safety 
- Provide high quality supply of food and feed,

- Plant Health, Animal Health and Welfare,

- Agricultural Infrastructure and Rural Development

- Institutional capacity

\section{Agricultural Vision for the Year 2023}

The main target of Agricultural Vision were determined as; Turkey on the road to 2023 being a country which;

- Provides its population with sufficient, best quality and safe food,

- Develops its net exporter position in agricultural products,

- Increases its competition power,

- Is a leader in the field of agriculture both in its own region and in the world.

The sectors targeted by the Programme are; milk, meat, fruit and vegetables and fishery sectors under the measures "investments in agricultural holdings" and "processing and marketing of agricultural products" including organic sector. The programme also includes the measure Diversification of rural development activities" in which on-farm activities (bee-keeping, pharmacological-aromatic plants and ornamental plants), rural tourism, local products and microenterprises and aquaculture production have been supported.

The papers aims to provide new ways of looking at sustainable organic agriculture and livestock production in Eastern Anatolia, Turkey in a systematic evaluation and propose a new domestic policy approach to rural development that is focused on facilitating change on the country side through more investment in human capital and entrepreneurial infrastructure. One should not forget that planning is different than the application of the plan. The paper also aims to evaluate the future methodology and approaches and their applicability under present conditions and their effectiveness. A balance needs to be found between the common good and scientific evidence about standard levels and economic interests of the people (Producers) involved in organic and conventional agriculture (Haşimoğlu, 2016). Preliminary conclusion was that "Turkey's best possible policy priority: investing in people".

Conventional and Organic Agriculture in Eastern Anatolia and Turkey

Despite a slow decline in recent years, agriculture and livestock production remains a major employer in Turkey and it is a significant contributor to the country's gross domestic product, GDP. Whilst Turkey is one of the EU candidate countries, is self-sufficient in food production and Turkish agriculture is poorly structured and inefficient, with farming in the Eastern Anatolia being mainly subsistence farming. Since 1983 the share of agriculture in GDP has declined from $21 \%$ to $13 \%$, and the agricultural workforce, as a share of total employment is also in gradual decline, falling from $35 \%$ in 2001 to $24 \%$ in 2013 - around 7 million workers due to outmigration from rural areas. Turkey is aiming to prevent migration from rural areas into urban areas (Especially from Eastern Anatolia to Western Turkey, or even to the EU). My calculations indicated that incomes in agriculture and livestock production are 3.6 times lower than in other sectors, and in the agricultural sector in Eastern Anatolia, they are much lower again than the Turkish average farmer's (Hassimoğlu, 2009 and 2016; Aksakal, et. al. 2015)

Turkey has an agricultural area of over 23 million hectares, over $15 \%$ of the current amount of EU27 agricultural land. The number of agricultural holdings decreased by $25 \%$ from 4 million in 1992 to 3 million in the 2001-census. The 2001-census also recorded an average farm size of around 6 hectares and indicated that around $65 \%$ of farmers have less than 5 hectares of land. Only $6 \%$ of holdings are larger than 20 hectares. The situation is worst with the addition of the landless agriculture workers and livestock producers in the region. More than $40 \%$ of the population of Eastern Anatolia live in rural areas and work in agricultural sector. Livestock is also an important component of the agriculture sector and the region has traditionally been an important supplier of live beef cattle, sheep / lamb, meat and other livestock products to the major cities of Western Turkey. A holistic approach to developing and improving supply chains could unlock the potential for sophisticated, state-of-theart organic agricultural and livestock producers and businesses in the region to become EU and global players. Eastern Anatolian livestock producers and the farmers have the ambitions to take part in future progress (Karaarslan, 2013; Ak, 2013; Aksakal et. al. 2015)

As it was indicated above, it should be indicated here again that most of Eastern Anatolian farmers are poor and can not effort to buy chemical fertilizer and chemicals (herbicides and pesticides). Only livestock manure is used as fertilizer on their fields which creates a good condition for the organic farming. Eastern Anatolia covers $18.9 \%$ of the total agriculture area and $11.8 \%$ of the total number of producers of Turkey. Region is far from the Mediterranean Sea and Black Sea, and has a high altitude that causes winters to be long and summers to be short. Winter season is often very cold and snowy, while the summer is cool in the highlands and warm in the lowlands. It is also known as the coldest region of Turkey, with an average low of $-25^{\circ} \mathrm{C}$ in winters. In Kars and Erzurum provinces, the number of days the ground is covered with snow is approximately 100 days a year. One of the advantages of the harsh climate is for instance the Wheat Disease called in Turkish Süne, caused by a Sunne pest has not been seen in Eastern Anatolia. It is due to cold climate and long freezing winter that kills the insects and mites. The region is also highly forested, being roughly $11 \%$ of the total forested area of Turkey and very convenient for wild harvest. The main economic activities in the Eastern Anatolia Region are animal husbandry and agriculture. The abundance of pastures in the region caused the number of animals to increase and priority was given to the production of farm animals and their products. In fact, the production of animal products in the region is about one fourth of the total production of 
Turkey. Only $1 / 10$ th of the whole region is arable. More than 90 percent of these arable lands are allocated for wheat and barley. The region is a plateau (Erzurum for instance is $2.000 \mathrm{~m}$ high from the sea level) which has advantages and disadvantages. Harsh and cold winters allow only one season for production whereas in other regions it is possible to obtain two or three different crops a year. The region is naturally organic not by design but default. It is for sure that present potential of the region has not been fully determined and utilized (Hasimoglu, 2012).

Eastern Anatolia with its immense experience in farming practices, harsh climatic conditions and rich biodiversity possesses a high potential for organic agriculture and livestock production along with other six regions of Turkey. Although organic farming and inconversion land constitute a small proportion of the total agricultural land in the region, this proportion is growing from year to year. Contract farming has been an important feature in organic agricultural production. This method enables contractors to ensure that the product meets certain standards and for producers to guarantee a previously agreed payment. It also requires well organized organic agriculture system and standards that are harmonized with the national and international norms.

Since the average farm size does not exceed more than 6 hectare the agriculture does not look very healthy and presence of landless farmer families make the situation worst in the region. In economic development the largest city in Eastern Anatolia Erzurum ranks $60^{\text {th }}$ among 81 provinces of Turkey. In this city of $2000 \mathrm{~m}$ high altitude and the lack of industrialization $34 \%$ of population is agricultural workers. Erzurum ranked $34^{\text {th }}$ among cities with the highest unemployment figures in Turkey. It is the reality that earning $\mathrm{s}$ of the farmers of the region is $1 / 3^{\text {rd }}$ of the average of the national farmer's earning that small farmers find it impossible to support their families off the land. Tens and thousands of villagers annually join extended families in larger cities Istanbul, Ankara and Izmir that places excessive demands on municipalities to build homes, educate a newly urbanized workforce, and provide basic infrastructure.

The role of education in eradicating poverty cannot be overstated. Organic agriculture is to a very large extent a knowledge system - farmers' in-depth familiarity with the conditions on their farm, and the appropriate management techniques to apply, are at the basis of organic production. That is why not only education but organic farmer education plays a very important role. Education of the farmers and livestock producers is the foundation for higher living standards and an important tool in the longterm eradication of poverty. Historically, education has only been available in the cities and larger towns and there is still a long way to go before that imbalance redressed. Right now, according our records which represent the farmers population of the 3,500 members of DOGTARBESBIR (Doğu Anadolu Tarım ve Besiciler Birliği- a farmer association), $20 \%$ are illiterate, $40 \%$ primary school, $20 \%$ middle school and $15 \%$ high school and $5 \%$ university graduates and only $12 \%$ are women.
Education and training are key factors in helping the East Anatolian farmers and livestock producers move from traditional farming to improved, organic agricultural practices.

\section{European Union and Turkish Government Relations}

Turkey is the largest and most populous country that was ever accepted for membership negotiations and it would be the first Islamic state (October 3, 2005). EU has greatly benefited from previous enlargements economically, politically and socially and accession of Turkey to EU would be the logical consequence of the previous successful accessions. In this context, the analytical examination of the screening in 35 chapters was completed during bilateral meetings in October 2006. The screening on chapter 11 (agriculture and rural development) was conducted between December 2005 and January 2006. The EU Council Presidency informed Turkish authorities in January 2007 on the opening benchmark that must be met before opening effective negotiations on chapter 11- Agriculture and Rural Development. Turkey is working to meet these benchmarks. Altinay (2010) indicated that the prospect of EU accession provided much needed credibility and served to anchor Turkey's economic future. The Copenhagen criteria, in turn provided the parallel roadmap for Turkey's political transformation. Between 2002 and 2004, political parties with diverse ideologies and priorities agreed to support several waves of EU political reforms. Transatlantic Trends (2011) survey reported that Turkish public opinion had dramatically decreased from $73 \%$ in 2004 down to $38 \%$ in 2010 but lately went back to $48 \%$ in 2011 and it looked like Turks (Rather Turkish present AKP Government) are turning away from the West and instead looking toward their Middle East neighbors.

Certainly membership of Turkey would make the EU a truly an economic and agricultural player between EU and Middle East states. Transatlantic Trends (2011) found out that half of those polled in the $12 \mathrm{EU}$ countries disagreed that Turkey's membership would be good in economic terms for the EU while 39\% agreed that it would be economically beneficial. Yet, the political courage and leadership among the leading European decision-makers appears to be waning in view of growing public fears about Turkey's accession to the EU - largely fuelled by populist politicians and media coverage that highlights cultural differences rather than similarities, (Aerni, 2007) . On average of $48 \%$ of EU plurality and majority of Americans (54\%) agreed that Turkey's membership would help promote peace and stability in the Middle East. However this was not shared in all EU countries; majorities in France (59\%), Netherlands (51\%) as well as plurality (46\%) Slovakia disagreed. It should be stated here that religious differences is another factor that increases the rejection of the Turkey's accession into EU. In spite of that last year (2010) 53\% of EU population still thought that Turkey' membership was likely. Romanians and Swedes (66\%each) as well as British (65\%) and 
Holland $(60 \%)$ were the most likely to think that Turkey would join the EU (Transatlantic Trends, 2011).

European Commission, (2009) reported that concerning agriculture Accession Partnership (AP) is a very important stimulus package for the Turkish agriculture. The revised Accession Partnership 2007 serves as a basis for future political reforms and as a yardstick against which to measure progress. Four priorities in agriculture and rural development included in the 2007

\section{Access Points (Solutions) \\ Short term:}

- Establish an IPARD agency (instrument for Preaccession Assistance Rural Development Component) accredited in compliance with EU requirements. Ministry of Agriculture is behind the schedule and too much bureaucracy is involved for the NGOs (Non Government Organization) and hard for them to follow the requirements.

- Lift restrictions on trade in beef meat, live bovine animals and derivate products.

\section{Medium term:}

- Continue developing the system of land identification and the National Farmer Registration System to prepare for controls on agricultural land.

- Start preparing the implementation of pilot actions relating to environment and the countryside, in view of future implementation of agricultureenvironmental measures.

The Instrument for Pre-accession Assistance- IPA (2011-2013)

Turkey received $€ 2616.9$ million for the years 2011 2013. In the case of agriculture and rural development $23 \%$ of the IPA funds, Component I. (Transition Assistance and Institution Building), Component $\mathrm{V}$. (Rural Development). However it is not known how much or what percentage would be designated to the development and improvement of the organic agriculture, especially for the Eastern Anatolia. When the leadership runs out of efforts, economic and agricultural growth can not just rely on EU transfers and foreign direct investments. Here the important issue is to promote agriculture education, organic agriculture techniques in human capital, especially for the young girls and women.

Possible Development and Changes in Turkey and Eastern Anatolia to Encourage Better Education and Entrepreneurship

Subsistence and semi subsistence farming is an important characteristic of Turkish agriculture. These farms are typical characterized by productivity of the factors of production being low and only small fraction of production being marketed as we observe in the Eastern Anatolian farmers. Aerni (2007) stated that as it is the case in many Eastern European countries, the pressure for reform and changes in Turkey comes from foreign institutions, be it the World Bank, the IMF, The WTO or
EU. So far, the EU had the biggest impact on Turkish reform policies, including agriculture. The EU is having a significant influence on Turkish Agricultural reform policy due to the big incentives for Turkey to eventually become an EU member state and benefit from EU direct payments (The first pillar of CAP) and the funds available for structural and cohesion policies. In recent years the CAP reform is shifting more support from direct payment (pillar 1) to rural development (pillar 2) and the structural cohesion funds have become more straightforward in their priorities. On the other hand he has recommended that besides EU direct payments, ARIP (The World BankAgriculture Reform Implementation Project) should be used to encourage better education and entrepreneurship. ARIP plans to reduce state intervention in agriculture by converting agricultural sales cooperative unions into farm oriented business companies. Moreover it provides farmer incentives to shift production away from subsidized crops. Further, suggested to use a cross compliance scheme that links direct payments to the condition that farmers send their children to school (especially the daughters)? Special awards would be given to for every child that completes secondary education. The highest award could be reserved for families whose offspring managed to become self employed and generate new jobs. It would generate the necessary human capital that would eventually be able to make use of the new technologies of the knowledge economy. In addition the World Bank is investing over US Dollar 400 million annually in agricultural education (Agriculture Knowledge and Information Systems - AKIS) that the focus is always on issues such as external advice for food safety issues, complying with regulation, environmental issues, etc. There is hardly any mention of setting up information hubs in villages and train locals how to make use of new information and communication technologies to set up local business networks, create market place for their own low-tech innovations and get access to relevant information to make the right business decisions. "Why not start an experiment in Turkey to convert idle teahouses in rural areas into busy local centers of prime access to business and technical information that is relevant to local entrepreneurs."

It is the primary importance that effective public organic agriculture education and extension policy, new techniques and technology, knowledge transfer to stimulate the rural entrepreneurship. It seems like Turkish Government's commitment to the development of agricultural reforms is not strong as it is desired level. As it was diagnosed by (Aerni, 2007), Turkish Governments desire is to please all kind of rural constituencies and farm lobbies by raising the amount of subsidies whenever there are important upcoming elections. It indicates that the political culture and institutions in Turkey are more likely to result in more give away legislation than responsible policy reform projects. The lack of political will to resist special interests may also explain why Turkey still boasts one of highest Producer Subsidies Equivalent (PSE)/GDP in the OECD. Reforms in Turkey proved to be feasible if there was outside pressure or a severe economic crisis. 
Yet, the will to reform always seems to vanish once this pressure is gone. This lack of strength leadership in domestic policymaking may prove fatal for Turkey (especially for Eastern Anatolia) on the long run.

Apart from the fact that the effectiveness of the European Union approach toward sustainable agriculture and food safety seemed effective, however its effect on the organic sector of the Eastern Anatolia is quite questionable due to weak social policy approach especially toward women where the unemployment level is very high. Aernie (2007) (Cited in Economist, 2005), one lesson can be learned from China (Xingijang province) is the way it addressed the growing violent resistance of large ethnic and religious minorities in its rural area. Heavily investment in the local infrastructure and creating economic opportunities even attracted immigration from poorer neighboring states such as Kazakhstan, Kirgizstan and even from Pakistan. Similar applications in Malaysia that invested in human capital relied on human rather than natural capital in its efforts to boost economic growth that eliminated the country to be a breeding ground for radical Muslim fundamentalists. It is for sure that sustainable development of the organic agriculture for the Eastern Anatolia needs to include the creation of new economic opportunities through innovative agriculture, livestock production and off-farm activities. Another example is from Turkey and (Adaman and Özertan, 2007) reported that the Harran region, located in the South-eastern part of Turkey, is facing an increasing salinity problem due to excessive and inefficient irrigation practices. In their research paper, they survey 619 cotton producers in the region and analyzed their perceptions and practices towards soil salinity. The survey results indicate that formal education and training are the central factors that determine the farmers' awareness of the relationship between excessive irrigation and salinity. The recognition of the negative externalities resulting from the unsustainable use of irrigation by neighboring farms positively affects farmers' willingness to participate in collective action to deal with the salinity problem. Yet, the current institutional setting in the Harran region discourages collective action and farmer initiatives. Policymakers need to support the empowerment of the local farmers through better and locally-relevant education and training and provide adequate incentives for farmers to adopt more sustainable practices and technologies.

Eastern Anatolian Organic Agriculture and Investing in Education of People

Organic sustainability of agriculture rests on the principle that we must meet the needs of the present without compromising the ability of future generations to meet their own needs. Therefore, stewardship of both natural and human resources is of prime importance. Stewardship of human resources includes consideration of social responsibilities such as working and living conditions of laborers (Including girls and housewives), the education and needs of rural communities, and consumer health and safety both in the present and the future. Stewardship of land and natural resources involves maintaining or enhancing this vital resource base for the long term.

This complex systematic approach also implies interdisciplinary efforts in research and education (Especially women because they are the one who take care of the family, livestock and farming activities). This requires not only the input of researchers from various disciplines, but also farmers, farm-workers, consumers, policymakers and others. Making the transition to sustainable agriculture through education investment is a process. For girls and women farmers, the transition to sustainable agriculture normally requires a series of small, realistic steps. Family economics and personal goals influence how fast or how far participants can go in the transition depends on the education level of the involved community. It is important to realize that each small decision can make a difference and contribute to advancing the entire system further in the organic agriculture of Eastern Anatolia.

Finally, it is important to point out that reaching toward the goal of sustainable organic agriculture is the responsibility of all participants in the system, including farmers, laborers, policymakers, researchers, retailers, and consumers. Each group has its own part to play, its own unique contribution to make to strengthen the sustainable agriculture community of Eastern Anatolia. The key to moving forward is the will to take the next step by the Ministry of Agriculture and Livestock Production of Turkey.

\section{Conclusion}

Final conclusion was that "Turkey's best possible policy priority: investing in rural agriculture people. As it was indicated earlier, authors conclude that the best way to promote sustainability as well as competitiveness of Turkish agriculture is to invest in the local people through improved education in general and effective agricultural training programmes in particular and give priority to women farmers. More investment in human capital leads to more entrepreneurship and innovation and eventually results in more employment opportunities and social empowerment. The lack of will or ability to address the problems of rural development through innovation policy rather than social policy may result in more local political discontent that people will express the growing frustration with the lack of economic opportunities. More investment in human capital leads to more entrepreneurship and innovation and eventually results in more employment opportunities and social empowerment. In the view of the fact that Turkey's agriculture still enjoys rather strong protection and profits from preferential market access to the EU. Turkey committed itself to reshuffle its agricultural support through some measures such as subsidies that are still considered to be legitimate in government agriculture policies. Yet, these traditional rural structures (Especially in East Anatolia and East Black Sea regions) combined with poor access to education and few off-farm employment opportunities 
produce a serious underemployment problem that is socially unsustainable that also causes migration from rural areas into urban areas. Rapidly developing organic agriculture and developed rural social policy is not in a position to create employment through new markets. In this context, Turkey's current efforts to make its agriculture more compatible with the EU's Common Agricultural Policy (CAP) that will increase the export opportunities for the organic produce.

\section{Acknowledgment}

Authors have written this article based on the planned activities of the project that has received funding from the European Union (EU)/Turkish Government through the key action: Strengthening the rural development-(CSDIV/AGR); Reference: CFCU/TR201/0135.15-08. European aid/136860/ID/ACT/TR.

\section{References}

Adaman F, Özertan G. 2007. Perceptions and practices of farmers towards the salinity problem: the case of Harran Plain, Turkey. International Journal of Agricultural Resources, Governance and Ecology 2007 - Vol. 6, No.4/5 pp. 533 - 551 http://dx.doi.org/10.1504/IJARGE.2007.013510

Aerni P. 2007. Editorial: agriculture in Turkey -structural change, sustainability and EU-Compatibility. Int. J. Agricultural Resources, Governance and Ecology, 6 (4/5): pp 429-439.

Altinay H. 2010. Does Fairness Matter in Global Governance? The Brookings Institution, October 10, 2010.

Ak İ. 2013. Türkiye'de Ekolojik Hayvancilık. Türkiye II. Organik Hayvancılık Kongresi (Yurt dışı katılımlı). Uludağ Üniversitesi. S: 163-173, 24-26 Ekim 2013. Görükle, Bursa.

Aksakal V, Karaalp M, Bayram B, Pehlivan E, Öztürk AK, Dellal G, Haşimoğlu S. 2015. Organik Hayvancılık Geliştirme Stratejileri:Sorunlar-Çözüm Önerileri. Doğu Karadeniz II.Organik Tarım Kongresi (Çağrılı Bildiri) 6-9 Ekim 2015, Rize.
GTHB 2016. Gıda Tarım ve Hayvancılık Bakanlığı Organik Tarım İstatistikleri, www.google.de/\#hl=de\&q=GTHB+ORGANIK+ TARIM+ISTA TISTIKLERI

Haşimoğlu S. 2009. Growing and finishing beef cattle strategies and environmental concerns of Turkish livestock production. $1^{\text {st }}$ International Congress on Global Climate Change and Agriculture. May 28-30, 2009, Namık Kemal University, Tekirdag/Turkey

Haşimoğlu S. 2012. Länderbericht Türkei. Biolanbau als Hoffnung für arme Regionen. Ökologie \& Landbau. 1/2012 pp. 52-53, FiBL. 4wsws22

Haşimoğlu S. 2012. Evaluation of Future of Europe and Turkey on Per Adult Human Unit (PAHU) and Per Capita (for the years 1999-2010. (Unpublished). Schwerin, Germany.

Haşimoğlu S. 2013. Kadının organik/konvansiyonel tarım ve hayvancılıkta üretici ve tüketici olarak yeri, katkısı ve bu katkının artırilması olanakları. Türkiye II. Organik Hayvancılık Kongresi. Uludağ Üniversitesi, Görükle, Bursa 24-26 Ekim, 2015; ss.45-56

Haşimoğlu S. 2016. Organik Tarım ve Hayvancılıkda Kayıt Tutma ve İç Denetim Sistemi. Ders kitabı. (Basıma hazır - 422 sayfa). Schwerin, Almanya (Planned to be published by University of Bayburt, Bayburt.)

Karaarslan V. 2013. Türkiye de ve Doğu Karadeniz de Organik Tarım. Gıda Tarım ve Hayvancılık Bakanlığı OTBİS kayıları. Doğu karadeniz 1. Organik Tarım Kongresi, ss: 13-23. 26-28 haziran 2013, Kelkit, Gümüşhane.

Karagel ÜD. 2010. Türkiye Koşullarinda Tarımda Çalışan Kadin Nüfus (1999-2010). Uluslararası Sosyal Araştırmalar Dergisi. Cilt: 3, Say1: 13, s: 254-267 (Özel Bask1). Ducecam@ firat.edu.tr

MALP. 2013. Ministry of Agriculture and Livestock Production, Structural changes and reforms on Turkish agriculture. http://www.tarim.gov.tr/Belgeler/ENG/changes_reforms.pdf

Transatlantic Trends. 2011. Section 6, Continuity and Change in Turkey. Transatlantic Trends 2011, p.37. Ministry of Foreign Affairs, Sweden. www.flad.pt/wp-content/uploads/2014/05/ livro02.pdf 